\title{
Conjugalidades Clericais na Diocese de Goiás, 1824-1907
}

Clerical Conjugalities in the Diocese in the State of Goiás, Brazil, 1824-1907

\author{
Maria da Conceição SILVA ${ }^{\bullet}$ \\ Wellington Coelho MOREIRA ${ }^{\bullet \bullet}$
}

Resumo: A prática do concubinato clerical foi um fato notório e atingiu o exercício do sacerdócio nas várias localidades da Diocese de Goiás no século XIX. O período a ser analisado limita-se a identificar, a partir da documentação eclesiástica e civil, o sentido dado à palavra concubinato e às várias modalidades de famílias compostas por padres desta diocese. Os bispos que assumiram essa sede prelatícia tentaram combater e normatizar a quebra do celibato em Goiás, no entanto, não obtiveram o êxito desejado, o que permitiu aos clérigos goianos a formação de uma família totalmente heterodoxa aos cânones do Concílio de Trento e da primeira legislação eclesiástica formulada em solo brasileiro - as Constituições Primeiras do Arcebispado da Bahia-. O clero goiano não esteve imune ao modus vivendis da população local, ao contrário, o seu modo de vida é em grande parte similar e correlato ao dos leigos.

Palavras-Chave: Conjugalidades Clericais; Igreja; Celibato; Documentação Eclesiástica.

Abstract: The practice of clerical concubinage was a notorious fact and reached the practicing of priesthood in several locations in the Diocese in Goiás, Brazil in the XIX century. The period to be analyzed is limited in identifying, from the ecclesiastical and civil documentation, the sense given to the word concubinage and the several modalities of families composed by priests from this diocese. The bishops who took up this prelatic episcopal seat tried to struggle and normalize the celibacy break in Goiás, however, they were not succeeded, fact that allowed the clergymen from Goiás the formation of a thoroughly heterodox family to the canons of the Council of Trent and of the first ecclesiastical legislation formulated in Brazilian soil - the First Constitutions of the Archbishopric of Bahia. The Clergy from Goiás was not immune against the modus vivendi of the local population, on the contrary, the way of life is largely similar and correlated to the laymen's one.

Keywords: Clerical Conjugalities; Church; Celibacy; Ecclesiastical Documentation.

O concubinato clerical foi uma realidade visivelmente presente entre os padres que compuseram a Diocese de Goiás no século XIX. O corte temporal desta pesquisa dá-se em função da efetivação de um prelado na Diocese de Goiás com a chegada de seu primeiro bispo, D. Francisco Ferreira de Azevedo em 1824, estendendo essa análise até o final do governo episcopal de D. Eduardo Duarte Silva em 1907, quando foi criada a Diocese de Uberaba pelo desmembramento desta da Diocese de Goiás. A presença de uma autoridade episcopal não significou a erradicação dessa prática familiar composta por clérigos. A Igreja diante da forma de conjugalidade tentou impor-se por meio de suas normas e preceitos morais debelando-se contra as

\footnotetext{
- Professora Doutora - Departamento de História e do Programa de Pós-Graduação em História - UFG - Univ. Federal de Goiás - Campus Samambaia - C.P. 131, CEP: 74001-970, Goiânia, Goiás, Brasil. Email: mariacsgo@yahoo.com.br

-• Mestrando do Programa de Pós Graduação em História da Faculdade de - UFG - Univ. Federal de Goiás - Campus Samambaia - C.P. 131, CEP: 74001-970, Goiânia, Goiás, Brasil.

Email: wellimoreira@hotmail.com
} 
famílias constituídas por sacerdotes. Desde os primórdios do catolicismo o rompimento do celibato constitui-se um problema efetivo para o magistrado da Igreja. A formulação conceitual do concubinato clerical possui indubitavelmente uma inter-relação com as concepções eclesiásticas de celibato (castidade) e casamento. A definição desse termo é polissêmica e constantemente sua terminologia foi (re)formulada pelos eclesiásticos e por outras pessoas que se envolveram nesse processo, dentre eles os padres concubinos. A grosso modo, a palavra concubinato assumiu uma conotação pejorativa e depreciativa em relação à mulher. Fato é que aqueles que deveriam propagar a fé e a moralidade cristã sucumbiram diante da vivência de uma conjugalidade possível, tendo além de uma companheira estável ou passageira uma prole numerosa.

O sertão de Goiás oitocentista foi um espaço favorável à constituição dessas famílias sacrílegas, haja vista que a sociedade em que esses sacerdotes se inseriram conviveu naturalmente com este tipo de conjugalidade. Os testamentos de padres goianos e outras fontes civis do século XIX trazem à tona um modo de vida contrário ao modelo tridentino e às normas preconizadas pelas Constituições Primeiras do Arcebispado da Bahia, de 1707. Concomitantemente, pela análise documental vê-se que a humanidade dos sacerdotes acabou por se sobrepor ao celibato idealizado pela Igreja. Certo é que a reforma moral dos costumes dos clérigos pretendida pela Igreja nunca foi alcançada, pois em qualquer sociedade existem modos distintos de comportamento e de interpretação de uma dada realidade. Certeau, a exemplo, acentua que a existência de instituições disciplinadoras não implica necessariamente na aceitação e na submissão às normas reguladoras por elas impostas. Para ele, os indivíduos e grupos sociais se (re)apropriam do espaço sócio-cultural organizado por práticas cotidianas concedendo a ele novos significados e sentidos. Desse modo, o autor assevera que:

Se é verdade que por toda a parte se estende e se precisa a rede da 'vigilância', mais urgente ainda é descobrir como é que uma sociedade inteira não se reduz a ela: que procedimentos populares (também minúsculos e 'cotidianos') jogam com o mecanismo da disciplina e não se conformam com ela a não ser para alterá-los; enfim, que 'maneiras de fazer' formam a contrapartida, do lado dos consumidores (ou 'dominados'?), dos processos mudos de que organizam a ordenação sóciopolítica (CERTEAU, 2001, p.41).

A ortodoxia católica na Diocese de Goiás oitocentista foi subvertida pela prática e pelos modos com que o cotidiano dos padres foi (re)configurado pela geração de famílias sacrílegas que se constituíram à margem dos códices canônico referentes aos Sacramentos da Ordem e do Matrimônio. Tais conjugalidades possuíram reconhecimento social e eram conhecidas e aceitas pelo "pasto espiritual" desta Diocese. Muito mais do que um crime moral contra a carne e o espírito, o concubinato de clérigos representou um delito, uma debelação (re)velada dos padres contra as normas idealizadas pela Igreja. A humanidade dos padres acabou por vencer a regra. 


\section{Da Etimologia Latina aos Documentos Eclesiásticos}

A palavra concubinato (concubinatus) em sua etimologia latina faz menção nas derivações que dela resultam a "coito" (concubinis); "que dormiu junto" (concubitus) ou "que dormiu com outro" (concubare); ou ainda, a "deitar-se com" (concumbere) (BARBOSA; et. al., 1967, p.128). Segundo Torres-Londoño, a origem histórica desta palavra situa-se no Império Romano, mais especificamente ao tempo do Imperador César Augusto. Segundo ele, o concubinato (concubinat) era uma designação dada à forma de relacionamento ilícito "em razão da classe de mulher que nelas se evolvessem”, portanto, “designava as relações maritais tidas com mulheres inferiores ou de comportamento duvidoso" (TORRES-LONDOÑO, 1999, p.21). São características centrais deste modo de relação no período citado pelo autor: - a permissão e a aceitação do concubinato pela sociedade romana e a não geração de vínculos matrimoniais-, isto é, a sociedade romana não reconhecia legalmente o enlace entre os envolvidos. Outros significados trazem o Diccionario da Lingua Brasileira, século XIX, descrevendo o concubinato como "amancebamento", sendo que a verbete mancebo faz menção a "moço na idade" apta a casar, enquanto que manceba, verbete feminina, significa "concubina" e mancebia "estado de amancebamento", ou ainda, "casa de prostituição". O ato de amancebar-se, segundo o mesmo dicionário, equivale a "tomar por sua conta huma mulher para tratar illicitamente com ella" (PINTO, 1996). Curioso e significativo é que os vocábulos masculinos acabam referindo-se sempre ao homem na idade apta ao casamento sem nenhuma referência depreciativa do mesmo, enquanto os vocábulos femininos possuem uma conotação pejorativa em relação à mulher. A palavra celibato (caelibatus), por sua vez, é denominada por "estado de solteiro" (BARBOSA; et. al., 1967. p.79; PINTO, 1996).

Faz-se necessário frisar que tais significações consolidaram-se a partir do século IV, quando o cristianismo edifica-se enquanto instituição de fato. Começar-se-á a transformação, a mudança de significados correspondente à palavra concubinato, tendo em vista os ideais celibatários impostos ao clero de modo processual desde o $1^{\circ}$ Concílio de Niceia (325 d.C.) até o Concílio de Trento (1545-1563 d.C.), décimo nono concílio da Igreja Católica. Todavia, é um sínodo regional ocorrido em Elvira/Espanha em 303 d.C. que dará início a tentativa de uniformizar a Igreja em torno do celibato. Dois de seus cânones trataram necessariamente da relação de clérigos com mulheres e da abstenção de sexo e engendramento de filhos para o exercício do sacerdócio.

O cânon 27 do SYNODO DE ELVIRA concedeu aos padres a permissão de ter junto a si parentes próximos. Essa norma consolidou-se nos vários concílios da Igreja, estando presente nas Constituições Primeiras do Arcebispado da Bahia (VIDE, 2007, § 483-484, p.189-190) e nas recomendações pastorais de D.Claudio José Gonçalves Ponce de Leão, bispo da Diocese de Goiás de 1881 a 1890, dirigida de modo exclusivo e reservada ao clero goiano (LEÃO, 1885, p.17). 
Entretanto, o cânon 33 passou por reformulações conciliares e lutas entre clérigos que defendiam o celibato e outros que defendiam o acesso dos sacerdotes ao casamento, sendo definitivamente abolido o acesso a constituição familiar aos padres a partir do IV Concílio de Latrão (1215). Sobre os primórdios da Igreja, Vainfas (1986) afirma que esta teve como ideal de sua existência a busca pela castidade, tendo a virgindade e a ascese como ideais cristãos visados pelos primeiros crentes. Nas palavras de Tomás de Aquino a castidade "deriva do fato de a razão castigar a concupiscência". Esta tem a sua sede na alma, ao passo que a segunda, o corpo é a sua matéria (AQUINO, 2005, p.277). Dado é que esses ideais ascéticos se consolidaram basicamente a partir de uma corrente filosófica denominada estoicismo. Vainfas salienta que:

Nos inícios do cristianismo, a primeira literatura de cunho moral não priorizou nem o casamento nem a família - como muitos supõem -, mas o ascetismo, cujos valores essenciais eram a virgindade e a continência. Dirigida a homens e mulheres, tratou-se, em suma, de propaganda de renúncia, de luta pela castidade, e as interpretações doutrinárias da época extraíam dos textos apostólicos, em maior ou menor grau, tudo o que pudesse fundamentar (VAINFAS, 1986, p.7).

Com base nos escritos dos primeiros padres da Igreja, o autor, ainda, discorre sobre a virgindade da seguinte maneira:

Entre o fim do mundo terreno e a salvação possível, a virgindade era a garantia da ascese, o retorno à origem e à imortalidade, como dizia Metódio. Era, antes de tudo, a expressão da alma triunfante sobre a morte, sobre o devir, sobre o tempo. O corpo virgem, pregava Crisóstomo, era o templo da alma apta para o movimento ascendente rumo a Deus. Ser virgem era, assim, dedicar-se à contemplação, exercício inseparável, no dizer de Gregório de Nissa, da incorruptibilidade do corpo. Virgindade e verdade, virgindade e vida, virgindade e liberdade, eis associações recorrentes nestes discursos de renúncia. Renúncia que, no dizer dos Padres, significava exatamente o contrário, isto é, busca, ascese, libertação do mundo decadente, imortalidade. Espiritualização absoluta do corpo, a virgindade era mesma divina, conforme as palavras de Metódio (VAINFAS, 1986, p.8).

A alma foi caracterizada pelos intelectuais da primitiva Igreja como a substância mais próxima e capaz de ascender ao divino, enquanto o corpo foi pontuado como o locus das paixões que inebriam a alma e, consequentemente, afastam o homem de sua ascendência ao sagrado, a Deus. Faz-se então necessário purgar esse corpo, "cárcere da alma", apartando-se de toda e qualquer forma de prazer, diga-se em particular, do prazer sexual. A castidade passou a ser vista como uma forma superior de vivência da fé cristã, valorizando de sobremaneira a vida celibatária e, de modo particular, os clérigos, uma vez que estes lidam com as coisas referentes ao mundo espiritual, ou seja, o sagrado. Flandrin ao examinar a vida sexual dos casados na sociedade antiga avaliou os comportamentos morais dos casais pela ingerência da doutrina cristã em relação ao ato conjugal. Segundo o autor a união sexual foi considerada legítima somente dentro do casamento 
celebrado pela Igreja. No entanto, o prazer resultante dessa relação não era bem visto, fazendo-se necessário ordenar não somente as relações dos casados, mas o próprio corpo em relação aos prazeres que dele emergem. Postula-se que a cópula possui unicamente a finalidade de gerar filhos legítimos dentro de um modelo de família outorgado pelo magistrado da Igreja.

Há, no centro da moral cristã, uma desconfiança muito aguda em ralação aos prazeres carnais, porque eles mantêm o espírito prisioneiro do corpo, impedindo-o de se elevar em direção de Deus. É necessário comer para viver, mas deve-se evitar se entregar aos prazeres da gula. Da mesma maneira, somos obrigados a nos unir a outro sexo para gerar filhos, mas não devemos nos prender aos prazeres sexuais. A sexualidade nos foi dada somente para nos reproduzirmos. Utilizá-la para outros fins, como por exemplo para o prazer, é malbaratá-la (FLADRIN, 1987, p.135).

Aos padres a propagação da fé, o mundo divino. Aos leigos a propagação da espécie, o mundo temporal, portanto, profano. O sacerdote nesta ortodoxia deveria ser uma pessoa virtuosa, perfeita e de costumes condizentes com a função que ocupa (CONCÍLIO DE TRENTO, 2008, seção XXII, § 939, p.33). O Concílio de Trento ao definir o seu corpo doutrinário, notadamente ao se referir ao estado sacerdotal, confere-lhe estatuto de sacramento, fundamento essencial da doutrina católica de caráter normativo, coercivo e regulamentador. Uma de suas intenções eletivas foi a extirpação do concubinato de clérigos tendo por eixo dessa ação a sacralização do espírito virginal e do celibato. Exigiu-se dos eclesiásticos um autocontrole diante daquilo que foi considerado por mundano, o seu próprio corpo, a sua sexualidade. A abnegação ao amor carnal tornou-se um verdadeiro teste de resistência à própria humanidade dos clérigos. A sacralidade conferida ao Sacramento da Ordem rechaçou qualquer questionamento que engendrasse dúvidas acerca do sacerdócio católico e do celibato como condição no trato das coisas divinas. O exposto nos cânones 9 e 10 referentes à Doutrina do Sacramento do Matrimônio mencionou a anteposição pontuada pela Igreja em relação a esse sacramento e o Sacramento da Ordem, sob pena de excomunhão para àqueles que contrariassem a tal princípio:

Cân. 9. Se alguém disser que os clérigos constituídos em ordens sacras e os Regulares que professam solenemente castidade, podem contrair validamente matrimônio, não obstante a lei eclesiástica ou o voto, e que o contrário disto outra coisa não é senão condenar o Matrimônio; e que podem contrair matrimônio todos os que não sentem ter o dom da castidade, ainda que o tenham prometido - seja excomungado. Pois Deus não nega este dom a quem piamente lho pede, nem consente que sejamos tentados acima das nossas forças (1 Cor 10,13).

Cân. 10. Se alguém disser que o estado conjugal se deve antepor ao estado a virgindade ou celibato, e que não é melhor nem mais beato permanecer no estado de virgindade e celibato do que contrair matrimônio (Cf. Mt 19,11s; 1 Cor 7,25s 38.40) - seja excomungado (CONCÍLIO DE TRENTO, seção XXIV, § 979-980, p.39). 
A Igreja Católica a partir do Concílio de Trento estabeleceu definitivamente a invalidade do casamento sacerdotal, tornando-o sinônimo de concubinato, ato ilícito contrário aos normativos morais eclesiásticos, devendo essa forma de relação, que envolve clérigos, ser definitivamente extirpada do seio da Igreja. Os historiadores Silva e Lima ao discutirem a imposição da continência e do celibato no pontificado de Inocêncio III (1198-1216) certificam que esses foram pontos balizares do processo de reformulação e de reorganização da Igreja nesse período. Um dos pontos cruciais da reforma foi a diferenciação entre clérigos e leigos. Os primeiros deveriam viver a continência e a castidade, sendo o cerne dessa diferenciação o autocontrole do corpo.

O papado esforçava-se por distinguir os clérigos dos leigos. As autoridades romanas partiam da crença de que os clérigos pertenciam a um status superior ao do leigo, sendo, portanto, um grupo idealmente incorruptível e que deveria manter o antigo preceito estóico de apatia diante das coisas mundanas. Desta forma, o papado formulou estratégias para controlar mais de perto o comportamento de clérigos, pois os casados ou em concubinato não estavam habilitados, na perspectiva de Roma, para reger a ordem matrimonial, pois não preenchiam o principal papel almejado pelos reformadores romanos: o de serem imunes às práticas matrimoniais dos leigos (SILVA; LIMA, 2002, p.10).

Salienta-se ainda que:

A imposição do celibato aos clérigos regulares e aos seculares das ordens maiores estava relacionada a uma série de questões práticas, tais como a preocupação com a preservação do patrimônio eclesiástico e a necessidade desses indivíduos dedicarem-se integralmente às funções eclesiásticas. Contudo, também havia a convicção de que esses clérigos deveriam ser santificados, ou seja, estar separados dos demais por seu comportamento irrepreensível, abstendo-se dos prazeres, em especial os ligados ao corpo, distinguindo-se dos leigos, a fim de estarem mais próximos de Deus e aptos para os ofícios pastorais, assumidos depois da ordenação. Acreditava-se que só por meio de um corpo eclesiástico que se diferenciasse dos leigos e estivesse totalmente comprometido com as causas da reforma da ecclesia universalis poderia se alcançar à unidade da Igreja e a submissão dos fiéis (SILVA; LIMA, 2002, p.11).

Grageda ao esquadrinhar o celibato a partir do contexto de separação entre a Igreja e o Estado do México, questiona as diretrizes canônicas que instituíram a vivência da castidade sob o aspecto deidade. Segundo a autora, a Igreja mexicana no século XIX foi acometida de assalto pelos ideais liberais que puseram em xeque o âmago de suas diretrizes centrais. No tocante ao celibato, Grageda pontua que no campo dos apetites carnais os sacerdotes estão sujeitos as mesmas necessidades dos demais seres humanos. Ressalta ainda que a castidade imposta ao clero foi mais um preceito humano do que uma lei divina. Sua tese sustenta-se na história da Igreja e de seus concílios. Sua problemática assim se desenvolve: 
El celibato clerical no era una institución divina sino un precepto puramente humano, porque el "espíritu de la primitiva Iglesia" había sido contrario al celibato clerical, además de que ninguno de los seis primeros concilios generales habían establecido ley general al respecto (GRAGEDA, 2002, p.03).

Já a teóloga Ranke-Heinemann ao enfatizar processo de cerceamento do casamento eclesiástico desde o II Concílio de Latrão (1139), cujo ápice deu-se no Concílio de Trento, pontua incisivamente que o pano de fundo do celibato eclesiástico e da nulidade do matrimônio sacerdotal encontra a sua gênese na hostilidade ao sexo e ao casamento. Fato é que os padres desde os primórdios da Igreja mantinham relações conjugais e prole oriunda desta conjugalidade, embora houvesse certa animosidade por parte dos teólogos e papas da Igreja face a essa opção de parte significativa do corpo eclesiástico. Ao se estabelecer uma cerimônia formal e obrigatória para se contrair o matrimônio o Concílio de Trento criou uma condição de controle certeira na tentativa de impedir o concubinato eclesial.

\footnotetext{
Até então o casamento não exigia formalidades, ou seja, as pessoas podiam se casar em segredo, contraindo casamentos válidos sem sacerdotes ou testemunhas. Ao estipular que o casamento ocorresse perante o pastor local e testemunhas, a Igreja impedia que homens que se tivessem casado em segredo se tornassem padres. Assim depois de 1139 era impossível para os padres se casarem, e depois de Trento era impossível para os homens casados tornarem-se padres. Depois da época em que os padres podiam se casar, veio à época dos casamentos sacerdotais clandestinos e perseguidos. Depois de Trento o concubinato passou a ser a única saída, uma opção triste mas não raramente escolhida (RANKE-HEINEMANN, 1988, p.113).
}

No Brasil, muito tardiamente, a partir do século XVIII se formalizou a confecção de um corpo doutrinário de leis eclesiásticas fundamentadas no Concílio de Trento. A intenção seria a de regulamentar a situação da Igreja Católica e, concomitantemente, do clero disperso por estas vastas terras, essencialmente a parcela da Igreja presentes nos sertões brasileiros. Visou-se dar à Igreja fortalecimento e estabilidade em terras brasileiras. Para Riolando Azzi, a promoção de um catolicismo mais alinhado à Santa Sé Romana no Brasil ocorreu tardiamente, adquirindo vigor somente a partir de meados do século XIX. Segundo este historiador, os relatórios remetidos pela nunciatura apostólica no Brasil à Cátedra de Pedro destacaram criticamente a ignorância e a imoralidade do povo brasileiro e do clero em relação à doutrina moral da Igreja Católica, (AZZI, 1991, p.226-231). Fato é que a Igreja no Brasil desde o século XVI até o início do século XVIII foi uma instituição fragilizada tanto em sua organização eclesiástica quanto pela ausência efetiva de leis que lhe dessem rumo próprio. Em 12 de junho de 1707, deu-se início ao Synodo Diocesano convocado por D. Sebastião Monteiro da Vide, Arcebispo da Bahia, e em 21 de julho do mesmo ano se anunciou o resultado desse sínodo: As Constituições Primeiras do Arcebispado da Bahia ${ }^{\text {. A }}$ 
reforma moral do clero e do "pasto espiritual" católico brasileiro se tornou o norte principal visado por esse compêndio. Haja vista que um de seus alvos essenciais foi o concubinato. Nela se definiu o concubinato ou o amancebamento, como classificaram, como "uma illicita conversação do homem com mulher continuada por tempo considerável” (VIDE, 2007, § 979. p.338).

As Constituições ao se referirem ao amancebamento de clérigos brasileiros classificaram-no como um ato torpe e indigno de um ordenado, em consonância com o Concílio de Trento e com toda a trajetória histórica da luta eclesial entre a imposição do celibato versus a permissibilidade de acesso do matrimônio aos sacerdotes:

Considerando Nós quão indigna cousa é nos Clérigos o torpe estado do concubinato, pois sendo pessoas dedicadas a Deos, é maior nelles a obrigação de serem puros, e castos, e de vida, e costumes mais reformados, para que os fieis os não tenham por indignos do alto ministerio que tem, nem de sua deshonesta vida resulte opprobrio ao estado Clerical, conformando-se com a disposição dos Sagrados Canones e Concilio Tridentino, ordenamos, e mandamos, que se algum Clerigo Beneficado, em nosso Arcebispado, for convencido de estar amancebado com alguma mulher, pela primeira vez seja admoestado em segredo, que se aparte da illicita conversação, e faça cessar a fama, e escandalo (VIDE, 2007, § 994. p.342).

Note-se que a primeira observação tange à questão da pureza e da castidade daqueles que cuidam da administração das coisas sagradas. O clérigo que vive em estado de concubinato é tido por uma pessoa indigna de exercer o ministério o qual the foi confiado. Esse deve ser advertido em segredo, sem publicidade alguma. Visa-se por esta norma a preservação da imagem da Igreja, tencionando não maculá-la pela ação e humanidade de seus próprios pares. A admoestação por parte da Igreja deve resultar no cessar do escândalo e da fama do concubinato, isto é, almeja-se o fim da visibilidade e do reconhecimento público dessa conjugalidade. Para isso se exige que o clérigo "lance fora em termo breve" a sua concubina. A Igreja, por sua vez, dificilmente ou quase nunca conseguiu impor seu ponto de vista. Sua tentativa de normatizar a vida do clero e da população que lhe foi confiada dificilmente objetivou-se. Tais normas não atingiram a erradicação das práticas concubinárias de sacerdotes e leigos no cotidiano brasileiro.

Em Goiás, a primeira menção e definição ao concubinato data-se do dia 08 de agosto de 1734, na primeira Visita Pastoral ${ }^{2}$, que fez o Reverendo Doutor Alexandre Marquez do Valle, visitador ordinário da Capitania de São Paulo. Este visitador definiu o concubinato goiano como "o mal das minnas", uma vez que: "Seja costume inveterado de Minnas, viverem os Seus moradores na sensualidade com os entendimentos taó cegos, que esquecendose da Salvação das suas almas naõ acabaõ de conhecer a gravidade das occazioens proximas, e costumes de peccar" (VALLE, 1734, p.1v). Embora não nomeie diretamente os sacerdotes nessa perícope, a vida moral dos clérigos foi 
alvo central da visita realizada pelo padre visitador Alexandre. Nela se estabeleceu como obrigação aos padres que de

quinze em quinze dias haja conferencias de moral em o Lugar que o Reverendo Vigário da Vara assinar, as quais assistiráo todos os clerigos deste Arrayal, e noz outros destas minnas se faráo nas Capellas delles, tanto que ouver nelles de dous Clerigos inclusive para Sima, sob penna de Suspensáo de vinte oitavas por cada falta, e nellas prezidiráo o dito Reverendo Vigario da Vara, e capellaéns, os quais repartirão as materias que Se háo de definir, e faltando um sacerdote Sem cauza juxta que arbitrarão os taes Prezidentes estes o multarão na penna (VALLE, 1734, p.7v).

Esse visitador foi incisivo em determinar o fim de qualquer tipo de concubinato através da

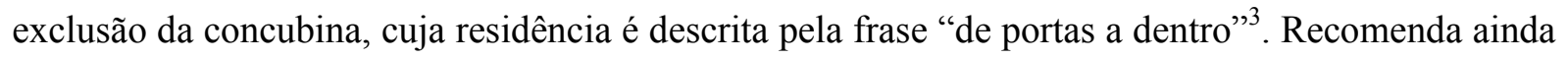
aos sacerdotes presentes em Goiás que preguem contra essa conjugalidade não outorgada pela Igreja (VALLE, 1734, p.2v-3). Segundo o Cônego José Trindade da Fonseca e Silva, "toda disciplina eclesiástica no território goiano dependia do Visitador ordinário ou extraordinário, sobretudo no século XVIII” (SILVA, 2006, p.79). Para Luis Palacín, o concubinato goiano se inscreveu num contexto de grande mobilidade da população mineira desencadeando um processo de miscigenação da população que aqui se formou, dada a presença maciça de homens nas minas. Outro aspecto citado por esse mesmo historiador refere-se aos altos preços cobrados pela Igreja para se ministrar o sacramento do matrimônio (PALACÍN, 2001, p.30-33, 77-98). Palacín também não fugiu a recorrência usual de analisar a origem das famílias goianas através dos escritos dos viajantes europeus. O problema do uso desses cronistas se encontra na forma com que a descrição foi averiguada sem que houvesse confrontação de fontes que afirmassem ou não as informações prestadas. O mesmo ocorre com as assertivas as quais certificam o concubinato como resultado do pecúlio cobrado para se realizar os casamentos e a ausência de mulheres brancas na fase aurífera dessa região.

Há na historiografia a fixa ideia de se ponderar quase sempre o concubinato como resultado das altas taxas cobradas pela Igreja ou de pontuá-lo como resultado do relaxamento moral dos costumes. Essas teorias devem ser relativizadas, pois elas não conseguem abarcar a complexidade da constituição dos vários modelos de concubinato e, em especial, do concubinato sacrílego. O cônego Luiz Antonio da Silva e Silva, em visita pastoral ordinária à Matriz de Santo Antonio e São Sebastião de Uberaba em 1824, descreveu o matrimônio como um vínculo indissolúvel tendo este por princípio o amor perpétuo entre os casais. Sobre a celebração do enlace matrimonial para as pessoas que não possuem condições financeiras para arrolar a documentação necessária para celebrar esse sacramento direcionou aos padres as seguintes recomendações: 
Não tendo chegado a esta Freguesia a Determinação Geral de Sua Excelencia Reverendissima a respeito dos cazamentos dos que são verdadeiramente pobres he preciso declarar que nos cazamentos daquelles, a quem o Reverendo Parocho em attenção a sua pobreza fizer proclamas, e certidoens, que lhes pertencem de graça, se lhes fação todos os papeis sem algum estipencio, devendo haver toda a circunspecção para que não se finjão pobres os que não são, e deixem de receber a graça de Sua Excelencia Reverendissima os que estão nas circunstancias a receber (SOUZA, 1824, p.124-124v).

Em portaria expedida por D. Eduardo Duarte Silva, datada em 12 de outubro de 1891, um dos motivos assinalados por este bispo para se conseguir a dispensa de um impedimento dirimente ${ }^{4}$ tange à questão da pobreza dos contraentes que anseiam celebrar o matrimônio (SILVA, 1891, p.13). Esse bispo nas visitas pastorais que empreendeu pelo interior de Goiás, em "pasto" para São José do Tocantins e a Corumbazinho, juntamente com alguns padres de sua comitiva, celebrou vários casamentos sem a exigência de formalidades, para se inventariar documentações (SILVA, 2007, p.96-97, 102-104). Frei José M. Audrin ${ }^{5}$ relatou que no interior, principalmente nas vilas mais distantes, as pessoas aguardam anos para "legalizar" o seu casamento, ficando sempre a espera de um padre ou missionário em festas e datas religiosas. Nessas datas festivas ou em um encontro fortuito com um padre naquela localidade, proporciona a realização de inúmeros casamentos religiosos (AUDRIN, 1963, p.142-151).

Os viajantes europeus foram um dos responsáveis pela efetivação da imagem depreciativa do concubinato que se formalizou na historiografia goiana. Auguste Saint-Hilaire, estando na Cidade de Goiás em 1819, observou que a prática do concubinato era uma realidade presente no cotidiano da população. Esse viajante perfilou essa forma de conjugalidade denominando-a por amasiamento, dando destaque à forma natural como a população local vivia essa relação. São características dessa relação, a coabitação do casal e a presença de uma prole numerosa. Assim afirmou esse viajante:

Em nenhuma outra cidade o número de pessoas casadas é tão pequeno (1819). Todos os homens, até o mais humilde obreiro, têm uma amante, que ele mantém em sua própria casa. As crianças nascidas dessas uniões ilegítimas vivem ao seu redor, e essa situação irregular causa tão pouco embaraço a eles quanto se estivessem casados legalmente. Se por acaso algum deles chega a se casar, passa a ser motivo de zombarias. Esse relaxamento dos costumes data do tempo em que a região foi descoberta (SAINT-HILAIRE, 1975, p.53).

Outro viajante estrangeiro, Joahnn Emmanuel Pohl, em seu relato, Viagem ao Interior do Brasil, assim descreve criticamente o concubinato goiano:

Neste país a moralidade é extremamente baixa. A religião consiste na forma, não na essência. Ficam geralmente impunes todos os delitos, inclusive o assassinato. Os sagrados laços do matrimônio são aqui muito frouxos e pouco apreciados (POHL, 1976, p.142). 
A análise dos viajantes estrangeiros não leva em conta o processo de constituição histórica da eclesialidade católica em território goiano. Seus escritos se basearam em relatos de terceiros, tendo inclusões textuais posteriores aos fatos, além da seleção de dados realizados pela subjetividade de seu autor (SAINT-HILAIRE, 1975, p.13-16). Goiás, durante longo tempo, permaneceu sem a presença efetiva de um representante episcopal da Igreja, tendo ainda como agravante a presença de um clero sem a mínima consonância com as diretrizes da cúria romana, afora às várias interferências dos poderes políticos nas atribuições de fórum eclesiástico. A longa vacância de bispos na Diocese de Goiás foi um fato representativo para a história da Igreja goiana. Seu primeiro prelado foi conhecido somente no início de 1824 . Nesse período a única forma de se ter acesso aos normativos eclesiais seria pelas visitas pastorais, de modo periódico e esparso (SILVA, 2006, p.7891). A Igreja foi inoperante em firmar-se institucionalmente nesse sertão, o que ocasionou tanto aos padres quanto a própria população um modus vivendis totalmente alheio às normatizações impostas por concílios e sínodos. Soma-se a este fator a grande extensão territorial, a presença escassa de um clero que acabou por associar-se a uma dinâmica de vida e a uma religiosidade nada ortodoxa.

Quanto à colocação do concubinato pela asserção de relaxamentos dos costumes, TorresLondoño pontua que essa tipicidade conjugal é resultado do afeto que "unia esses homens e mulheres, que sem vínculos jurídicos tinham vários filhos juntos e compartilhavam anos de vida" (TORRES-LONDOÑO, 1999, p.80). As relações consensuais foram legitimadas pela vivência diária do amor e do afeto de cada casal, sendo reconhecidas pela comunidade em que se inseriram esses vínculos conjugais. Vainfas considera que a única diferença entre essa conjugalidade e o casamento católico residiu na benção sacerdotal. Pois:

\begin{abstract}
A bem da verdade, faz-se necessário reler o lugar que o concubinato ocupava na sociedade colonial, desvinculando-o de vez da idéia de que era ele, necessariamente, uma espécie de casamento informal, uma conjugalidade de fato que, como tal, podia subsistir o casamento legítimo.

É verdade que os estudos calcados nas visitas diocesanas indicam que, em vários casos, os amantes 'viviam de portas adentro', 'viviam como se fossem casados', tinham e criavam filhos. Não resta dúvida de que, nestes casos, está-se diante de uma autêntica conjugalidade que nada devia ao legítimo casamento, exceto a falta benção sacerdotal à união. Não era, a bendizer, uma falta desprezível aos olhos da comunidade, já que tais casais de 'portas adentro' eram apontados como concubinários ao visitador eclesiástico. Mas é presumível que, não fosse a presença da Igreja, tais casais seriam deixados em paz, ensejando, quando muito, futricas e murmurações sem maiores conseqüências (VAINFAS, 2007, p.237).
\end{abstract}

O sertão de Goiás oitencentista foi um ambiente cultural propício à fecundidade das conjugalidades clericais, cuja vivência era reconhecida e aceita pela sociedade em que os padres se inseriram. Pode-se então definir o concubinato clerical como a família negada pelas normas 
eclesiais, mas vivenciada de modo intenso pelo sacro e humano corpo eclesiástico dos goyazes oitocentista.

\section{O “Ser-Tão" Goiano das Conjugalidades Clericais}

No século XIX a prática do concubinato clerical foi um fato notório e atingiu circunstancialmente o exercício do sacerdócio nas várias localidades da Diocese de Goiás. A historiografia de um modo geral tece uma visão depreciativa acerca do sertão goiano oitocentista e, concomitantemente, sobre as conjugalidades clericais desse período, tendo por base os relatos e crônicas dos viajantes europeus ${ }^{6}$. Para Alencar, a conotação negativa do termo "sertão" se consolidou através das narrativas dos viajantes estrangeiros. Ao narrarem os seus intercursos pelos sertões do Brasil e, em particular, pelo sertão de Goiás, esses o avaliaram como lugares “"vazios de civilização', espaços atrasados, inóspitos, distantes", vistos sempre em oposição ao litoral, locus da civilidade (ALENCAR, 2000, p.244). O Diccionario da Lingua Brasileira, século XIX, define a palavra "sertão" como "o interior das terras; mato distante da costa marítima" (PINTO, 1996). Para Lima, o que está em discussão é a ideia que contrasta litoral e sertão, ou seja, civilização/progresso e atraso/ignorância (LIMA, 1998, p.35-53). Sobre o concubinato clerical pairam ideias similares e correlatas de incivilidade, uma vez que essa forma de conjugalidade sinaliza a ruptura da castidade tida como modelo superior de vivência da fé cristã, também sinônimo de ordem eclesial e social. O sertão de Goiás em sua conjuntura sócio-eclesial proporcionou ao clero a vivência de um estado de vida similar ao do laicato. As famílias compostas por esses sacerdotes foram assinaladas como uma antítese à civilidade instituída pelos normativos canônicos tridentinos. Um relatório de polícia, datado em 1866, deprecia o clero goiano pela inobservância do seu celibato, classificando o seu modo de vida como algo nefasto à sociedade (paroquianos). Este documento equipara esse hábito à má fama, desonra, ou ainda, mau procedimento ao enfatizar que:

Os parochos, em quanto o clero estiver no estado de abatimento e ignorância e descredito em que ora se acha, nada podem fazer, falta-lhes o prestigio que só pode ser dado pela virtude ou pela sciencia, por isso por muito tempo não se pode esperar d'elles cousa alguma em ordem ao ensino e moralização de seus parochianos, o seu officio ha de se limitar a pratica de alguns atos religiosos e nada mais (RELATÓRIO DO CHEFE DE POLÍCIA, 1866, Caixa 173).

Todavia, o sertão goiano deve ser compreendido como um espaço propício à circulação de culturas, que engendram uma civilidade e uma religiosidade favorável à constituição de conjugalidades sacrílegas. Esse sertão ora denominado pelo isolamento, ora certificado como lugar 
do atraso, é ambiente genesíaco de múltiplas expressões regionais e locais como afirma Victor Leonardi. $\mathrm{O}$ autor indica que Goiás foi palco de uma interpenetração cultural pela mesclagem de vários modelos culturais oriundos de localidades e regiões brasileiras e lusitanas diversas (LEONARDI, 1996, p.307-322). Assim deve-se intuir que as relações conjugais estabelecidas pelos padres se configuraram na necessidade afetiva e sexual dos clérigos, que constituíram um modelo de família singular em face da realidade em que esses estavam inseridos. Peter Burke, ao analisar a cultura popular na Idade Média, sugere que os modos de vida são compostos pela partilha de significados culturais, capazes de envolver tanto elementos da cultura em geral quanto aspectos assimilados da cultura regional. Não existe um modelo cultural homogêneo. O que existe é uma interação de culturas, trocas de sentidos e valores, via apropriação criativa daquilo que é apreendido (BURKE, 1993, p.50-89). Os normativos eclesiásticos, introduzidos pela ação da Igreja na Diocese de Goiás oitocentista, passaram por um processo de adaptação e acomodação cultural. A sociedade goiana conhecia e convivia naturalmente com famílias compostas por padres. O Jornal Provincia de Goyaz, datado de 9 de julho de 1870, em sua seção de óbitos, repassou juntamente com a notícia fúnebre a informação da existência de uma filha de um clérigo sob a titularidade de filha legítima. Veja o teor do documento:

FALLECERÃO - durante a semana finda: - o major reformado Joaquim Manuel de Oliveira, quatro ou cinco dias depois de haver-se casado; e D. Maria Xavier Serradourada, filha legítima do Revd. Vigário David Francisco Povoa, e mulher do Capitão Joaquim Martins Xavier Serradourada.

Recebão os parentes de ambos os finados as manifestações de nossos pesos (PROVINCIA DE GOYAZ, 1870, p.2).

Tal notícia ocupa-se em fornecer a informação dos falecimentos do Sr. Joaquim e da Sra. Maria Xavier e, ao mesmo tempo, em dar os pêsames aos familiares destes moribundos. Ambos eram pessoas reconhecidas socialmente. O jornal não se furta em noticiar que Maria Xavier Serradourada era filha de um clérigo. Como meio de divulgação de notícias esse periódico trouxe à tona de modo explícito o rompimento do celibato pelo Reverendo Vigário David Francisco Povoa. Como várias pessoas, famílias e grupos sociais tiveram acesso ao jornal não é exagero supor que o corpo social e eclesial da época tinha conhecimento da situação. Em Carta Pastoral Reservada dirigida ao clero, D. Claudio José Gonçalves Ponce de Leão foi contundente em afirmar que as desordens morais cometidas pelo clero goiano eram de conhecimento de todo o povo de Deus desta Diocese. Como bispo da sede prelatícia D. Claudio condena a imoralidade de clero sob o seu governo. O concubinato dos ministros de Deus foi por ele considerado um estado lastimável e uma abominação à salvação dos sacerdotes. Diante disso, asseverou que: 
As desordens, os crimes dos Sacerdotes são conhecidos de todos, pois estão collocados sobre o candieiro, estão todos e de continuo com os olhos sobre elles; condennados por todos; os mais culpados são os primeiros à condennar os erros de seus Irmãos, á torna-los ainda mais publicos; todavia cada um acha mil razões para continuar na sua vida escandalosa, para violar cada dia mais criminosamente as leis Santas de Jesus-Christo e de sua Igreja (LEÃO, 1885, p.1).

Sobre o concubinato e a vida pública do clero goiano continua a discorrer D. Cláudio:

Os mesmos Sacerdotes vivendo amancebados, sobrecarregados de outros muitos peccados mortaes, não deichão de celebrar em um só dia, pelo menos quando tem intensão de missa. - Passa o sacerdote a noute inteira dansando, em divertimentos profanos, perigosos até, comendo e bebendo, com tanto que elle durma antes da Missa, celebra sem o menor escrúpulo.

Perdestes a fé, infelizes Irmãos, está vosso coração mais endurecido do que estas pedras, já vossa consciencia está de tal sorte cauterizada, que comettendo o mais abominavel de todos os sacrilégios, todavia permaneceis tranquilos (LEÃO, 1885, p.13).

Segundo esse bispo, a vida moral e social do clero não se distinguia muito do laicato. "Pelo que temos dito é manifesto: A vida de muitos Sacerdotes de nenhum modo se distingue da vida dos seculares, e d'aquelles seculares mundanos, licensiosos, que só tem o nome de christãos" (LEÃO, 1885, p.28). Diante da situação em que se encontrava o clero, D. Claudio convocou em 1887 o Synodo Diocesano, tendo por objetivo principal dessa ação "produzir a correção dos costumes, a conservação e perfeição da disciplina clerical". Um dos temas centrais desse sínodo foi a "santa castidade". O que se almejou foi a reformulação dos costumes sacerdotais e o cumprimento dos deveres morais e religiosos dos clérigos (LEÃO, 1887, p.1-20).

O governo de D. Eduardo Duarte Silva, bispo de Goiás, de 1891 a 1907, também foi marcado pela presença de padres em regime de concubinato. Este bispo em uma de suas visitas pastorais em Bela Vista quando se direcionava à capital desse Estado para tomar posse de seu prelado, defrontouse com uma situação inesperada logo no início de seu governo. O padre daquela localidade ofereceu como gesto de acolhida ao recém-chegado bispo os serviços comensais na residência de um coronel, onde a prole do padre servia à mesa. Assim relata D. Eduardo este fato inusitado:

Eu disse a um dos padres que se informasse de quem era aquela casa e que pessoal era o que nos estava servindo.

Soube então que era o palacete do coronel Vicentão e que aquelas moças eram as filhas do vigário. Mandei que o chamassem, e, vindo ele, declarei-lhe que, se ali quisesse ficar com as filhas, que ficasse, indo eu para qualquer outra casa; se não quisesse, que se fosse para a sua casa com a sua infeliz prole. Muito magoado e chorando foi ter com um dos missionários e assim queixou-se: "Que mal fiz eu a este bispo para separar-me assim de minha mulher e de minhas filhas" (SILVA, 2007, p.85-86). 
Diante da resposta desse padre D. Eduardo perplexamente menciona: "Fiquei embasbacado à vista de tanta simplicidade e ignorância, para não usar outro termo" (SILVA, 2007, p.85-86). O que chama a atenção nesse episódio é o caráter público da relação conjugal. Aparentemente o texto deixa transparecer a aceitação dessa conjugalidade pela comunidade local. Basta notar que o fato ocorre na casa de um representante civil de prestígio daquela localidade. Como se serve um banquete é de supor que haja outros convidados para a recepção de D. Eduardo Duarte Silva. Mesmo com a presença efetiva de um bispo esse clérigo não escamoteou seu hábito de vida. Aliás, supõe-se pelo texto que o ato da revelação pública do concubinato clerical à autoridade eclesiástica partiu do próprio sacerdote. Diante da reprovação que lhe foi dirigida devido à ruptura de seu celibato, o padre parece não compreender o motivo da objurgatória e se retira condoído pelo modo como tal gesto foi interpretado. O sacerdote de certo modo não conseguiu entender quais foram os motivos que deram origem ao ríspido tratamento de D. Eduardo direcionado a sua pessoa e a sua família. O livro de tombamentos das paróquias da diocese de Goiás datado em 1920 traz a informação de que o nome desse padre era Pe. Braz da Costa Oliveira. A freguesia de Bela Vista ficou sob o seu governo de 1882 a 1899, sucedendo a este os Missionários Redentoristas em 1890. Porém, Pe. Braz reassumiu a paróquia novamente em 1901 (LIVRO DE TOMBAMENTOS DAS PARÓQUIAS DA DIOCESE DE GOIÁS, 1920, p.29-29v). Apesar de ter constituído uma família não aceita pela Igreja, esse padre permaneceu à frente da igreja local e no governo episcopal de um bispo romanizador com a clara consciência (e anuência?) da situação pelo chefe desse prelado.

Frei José M. Audrin, missionário dominicano presente no sertão goiano de 1921 a 1928, fez uma afirmação peculiar acerca da religião e do sentimento religioso goiano em seu livro, "Os sertanejos que conheci”. Para ele, a religião cristã era desconhecida pelos sertanejos dada as circunstâncias eclesiais de abandono da Igreja em relação ao pasto espiritual. Assim salienta:

Devemos lembrar que a instrução religiosa dos sertanejos não é completa e, por isso, como natural conseqüência, certas palavras, rezas, gestos e práticas rituais nem sempre estão de acôrdo com os princípios e as normas da verdadeira religião. Algumas hão de parecer-nos sugeridas por uma espécie de superstição e opostas ao bom senso cristão.

Não se julgue, todavia, que os exageros dos devotos sejam provas de fetichismo, de bruxarias e outras tolices ridículas, como teimam afirmá-lo alguns sertanistas mal informados ou mal intencionados. O mais certo é ver, em tôdas essas esquisitices, interpretações por demais ingênuas de crenças fortemente enraizadas, mas pouco esclarecidas (AUDRIN, 1963, p.119).

Por este fragmento confeccionado por um religioso é possível interpretar, que o sertão goiano proporcionou a formulação de crenças desprendidas da oficialidade das regras católicas. Castro, ao discorrer sobre a organização da Igreja Católica na Capitania de Goiás no século XVIII, assinala a existência de uma crescente e urgente demanda por sacerdotes que acompanhem pastoralmente o 
povo nesse sertão. Esse déficit fez com que os bispos ordenassem pessoas sem a mínima condição para o exercício do sacerdócio. Para Castro (2006, p.76): “A falta de vocação acabava sendo reforçada pela dificuldade pessoal para a prática do celibato”. Outra dificuldade encontrada pelos bispos tange a não existência de um seminário na diocese. Muito tardiamente se abre em Goiás um seminário para a formação do clero. Segundo o relatório apresentado à Assembleia Legislativa pelo então presidente da Província de Goiás, o Sr. Antero Cícero de Assis, o primeiro seminário episcopal teve seu começo em 06/01/1872 (ASSIS, 1999, p.115-116). Os anos subsequentes à sua abertura são assinalados pelas inúmeras dificuldades de mantê-lo em suas necessidades de subsistência, como afirma D. Eduardo (SILVA, 2007, p.93-94, 136-137, 157-158). A instrução seminarística tem por finalidade a formação e a normatização do clero e, consequentemente, visa à reformulação de seu estado de vida segundo as diretrizes tridentinas. Em 1824, o primeiro bispo de Goiás, D. Francisco Ferreira de Azevedo, na falta de instrumentos e possibilidades para formar e reformular o clero local, emitiu uma carta pastoral pedindo a todo corpo de sacerdotes que pudesse cooperar com a missão que lhes foi confiada, exigindo desses "decência nos costumes, decência no traje talar", citando para tanto as normas das Constituições Primeiras do Arcebispado da Bahia ${ }^{7}$, conforme afirma o Cônego Trindade (SILVA, 2006, p.141).

Apesar das dificuldades para abrir, manter e organizar o seminário em Goiás e dos demais obstáculos ligados à formação do clero, segundo D. Cláudio José Gonçalves Ponce de Leão, não se pode alegar falta de conhecimento sobre o celibato eclesiástico. Ele foi enfático ao dizer que na profissão sacerdotal todos assumiram conscientemente a vida casta. O padre, enquanto celibatário é por ele equiparado a um anjo, o seu inverso, o concubino, ao demônio. Para D. Claudio é:

No dia em que recebemos o subdiaconato promettemos todos à Jesus-Christo e à sua Igreja de guardar a perfeita castidade. É nesta obrigação, à respeito da qual não podemos allegar ignorância - christãos e herejes, sabios e ignorantes, todos conhecem este grande dever nosso. Todo homem venera o sacerdote casto como á um anjo, todos se receião dos sacerdotes desonesto como a um demonio (LEÃO, 1885, p.15-16).

Alguns sacerdotes que viveram em estado de concubinato foram exímios cooperadores e executores de serviços eclesiásticos nessa diocese. Contudo, o exercício do sacerdócio e o conhecimento de suas regras e normativos não implicou necessariamente na observância total dos preceitos tridentinos. Ademais, é visível nos testamentos deixados por eclesiásticos e por alguns de seus descendentes a dificuldade que teve o clero de se manter obediente a certas exigências canônicas, principalmente quanto ao quesito castidade. Certo é que nem todos os padres foram fiéis ao celibato exigido pela Igreja. Sobre a formulação testamentária, Miranda considera que a 
proximidade da morte permite que a pessoa prepare-se bem para morrer através do retrospecto de sua vida, principalmente suas relações sociais e familiares. Ressalta Miranda:

Por isso os testamentos refletem essa necessidade de repartir corretamente os bens, reconhecer publicamente os herdeiros e a legitimidade do direito a herança. Algumas vezes o testamento era também momento de reconhecer parentescos e relações não assumidas ou não legalizadas (MIRANDA, 2001, p.21-22).

O cônego Antonio da Silva e Souza foi um eminente religioso e ministro plenipotenciário do governo da época. Em muitas ocasiões assumiu a administração da Igreja goiana, dada a ausência de um bispo nesta localidade (TELES, 1977, p.56-64). Foi responsável pela confecção de um dos primeiros escritos sobre Goiás, intitulado Memória sobre o Descobrimento, Governo, População e coisas mais notáveis da Capitania de Goiás. Silva e Souza relatou nesse documento em uma nota de rodapé alguns crimes morais e administrativos cometidos por sacerdotes (TELES, 1977, p.7980). A respeito destes registros afirma Cônego Trindade, que "esclareceu com precisão os acontecimentos políticos nos fatos e feitos dos governadores, viu os crimes de padres relapsos e não registrou a virtude dos primeiros vigários das minas goianas" (SILVA, 2006, p.24). Discrepantemente, em seu testamento datado em 14 de abril de 1820, Silva e Souza assumiu ser pai de Maria Luiza da Silva e Souza. De acordo com o testamento, Maria nessa época se encontrava no Arraial do Tejuco, Serro Frio, em Minas Gerais junto às irmãs desse cônego. Antes mesmo de sua morte em 30 de setembro de 1840, Silva e Souza havia conseguido junto ao Tribunal do Desembargo do Passo a confirmação de legitimação de sua filha. A carta de confirmação de Maria Luiza encontrava-se com ela em Serro Frio, com a finalidade de resguardar o seu direito de herança (TESTAMENTO DO PADRE LUIZ ANTONIO DA SILVA E SOUZA, 1840, p.170-174).

O testamento do irmão de Silva e Souza, o Padre José Antônio da Silva e Souza, datado em 18 de julho de 1839, ao inscrever a distribuição da sua herança, traz a informação de que a sua sobrinha nesse período se encontrava junto a seu irmão, na Capital de Goiás.

Tenho mais duas moradas de cazas, huma em que moro, no Largo do Rosário e outras na Rua da Cambaúba; e outras assim mais em [Apolecer?], três contos, e oito centos mil reis, e destes deixo a minha Sobrinha Dona Maria Luiza da Silva e Souza, que está morando na casa de meu Irmão, o Senhor Conego Provisor, hum conto e oito centos mil reis (TESTAMENTO DO PADRE JOSÉ ANTONIO DA SILVA E SOUZA, 1839, p.155).

A filha de Silva e Souza em seu próprio testamento assim se declarou:

Declaro que sou filha legitimada do Conego Provisor Luiz Antonio da Silva e Souza, já fallecido e como tal me nomeou no testamento [?] que [?] sua Universal herdeira. Declaro, que sou solteira, e nunca fui casada, e nesta cidade sempre vivi 
em companhia do dito meu Pay, e não tenho parente assendente, ou descendente (TESTAMENTO DE MARIA LUIZA DA SILVA E SOUZA, 1846)

Após discorrer sobre a sua legitimação e moradia, Maria Luiza ainda relatou a sua transferência de Serro Frio para a Capital de Goiás, recapitulando este fato histórico pela iniciativa de seu pai.

Declaro que o dito meu Pay tendo feito o seu testamento nesta cidade no anno de mil oito centos e vinte, quando me achava em Serro Frio, para onde me havia mandado criar e trazendo-me no Regresso de sua viagem que fez para o Rio de Janeiro como Deputado, nas Cortes de Lisboa vim em sua companhia para esta cidade e vivendo junto com elle muitos annos, faleceu no anno de mil oito centos e quarenta com aquelle Testamento em que havia me instituido sua universal herdeira (TESTAMENTO DE MARIA LUIZA DA SILVA E SOUZA, 1846, p.11v).

Teles descreve a preparação desta viagem para o Rio de Janeiro no ano de 1822. Desta cidade Silva e Souza embarcaria para Portugal. Devido ao movimento de independência em curso no Brasil esse regressou à Goiás e reassumiu a sua cadeira de vigário geral (TELES, 1978, p.62). O conjunto de documentação traz a revelação da quebra do celibato por um clérigo de qualificada reputação civil e eclesiástica. Sua filha conviveu com ele durante um longo período em Goiás em dois momentos. O primeiro, sem precisar a data, nos anos iniciais de sua vida até ser transferida para a cidade de Serro Frio/MG. E, posteriormente, por quase vinte anos na Capital de Goiás. A sua legitimação ocorreu antes mesmo de seu pai confeccionar o testamento no ano de 1820 , sendo adquirida junto ao Tribunal do Desembargo do Passo via carta régia de confirmação, conforme os dados apresentados no testamento de Silva e Souza. De acordo com Neves

O objetivo dessas cartas de legitimação era, como fica evidente na legislação, habilitar e instituir como herdeiros os filhos nascidos de uniões ilegais e, no caso dos padres, os filhos sacrílegos.

Tinham os processos para a concessão de cartas de legitimação uma estrutura formal constante. Inicialmente, o indivíduo que solicitava a graça encaminhava uma petição ao rei, por meio do Desembargo, na qual expunha as inclinações e motivos pelos quais a demandava.

Esta petição era anexada a Escritura de filiação feita em cartório, na qual o requerente reconhecia por filhos quem queria instituir por herdeiros (NEVES, 1993, p.137).

O irmão de Silva e Souza, o padre José Antônio da Silva e Souza, também atesta a convivência entre pai-padre e filha em seu testamento. Não obstante este também teve um filho ilegítimo, que de acordo com o seu testamento sempre viveu e foi criado em sua casa: "Instituo por meu universal herdeiro á Cirilo Maximianno da Silva e Souza, meu filho natural, que se Criou em minha Caza, e foi baptizado por ingitado = Declaro digo por engeitado" (TESTAMENTO DO 
PADRE JOSÉ ANTONIO DA SILVA E SOUZA, 1839, p.155). Para tê-lo junto a si o padre José Antônio fez uso da norma eclesiástica que permitia a omissão do nome do pai na certidão de batismo, tendo em vista o escândalo que dela podia resultar, principalmente se a criança for filho de um clérigo. A Igreja tinha claro conhecimento da existência de filhos de sacerdotes tanto que formulou regras batismais para regularizar e/ou esconder essa situação (VIDE, 2007, § 40 e 73, p.16 e 39).

O período de convivência entre pais e filhos na capital de Goiás revela que a sociedade da época conhecia e convivia naturalmente com essas famílias, haja vista que os filhos residiam na casa de seus pais-padres. Como as mortes do cônego Antônio da Silva e Sousa e de seu irmão ocorreram no ano de 1840 , é de se questionar até que ponto a Igreja na pessoa do Bispo D. Francisco Ferreira de Azevedo e de seus auxiliares de fato tiveram ciência ou não dessa situação tão notória. Será que conscientemente a Igreja se omitiu diante destas paternidades que não se constituíram como casos isolados? O padre José Iria Xavier Serradourada, por exemplo, falecido em 04 de setembro de 1898, trouxe à tona a revelação da transgressão de seu celibato, sugestionado pela inscrição "por fraqueza humana". Apesar de dizer professar viver e morrer na fé católica, Pe. José Iria assumiu ser pai de dois filhos com duas mulheres diferentes. Ambos os filhos residiam na Cidade de Goiás próximo ao seu genitor.

Declaro que por fraqueza humana tive uma filha de nome Benedicta, com Maria Joaquina da Rocha e um filho de nome Benedicto, com Norberta da Silveira Borges, ambos solteiros; cujos meus filhos existem vivos n'esta Capital, estimando-me e respeitando-me com todo o affecto e carinho; e como não os tivesse ainda sido reconhecidos, os reconheço por meus filhos por meio d'este testamento e de conformidade com as leis que regem esta matéria (TESTAMENTO-CERRADO DO PADRE JOSÉ IRIA XAVIER SERRADOURADA, 1898, p.2v).

Um dos cernes centrais desse testamento foi o reconhecimento da paternidade via instrumento legal, uma vez que anteriormente isso não havia sido feito. Revelou-se também a existência de uma relação próxima entre o padre José Iria e seus filhos sacrílegos: "estimando-me e respeitando-me com todo o affecto e carinho". O sacerdote-pai conviveu cotidianamente próximo de sua prole. Diante disso, é possível ver que os filhos de padres "não eram simples 'bastardos'," (FRAGOSO, 1992, p193), pois pais (padres) e filhos viveram na capital, sede do bispado, muitos desses filhos de padres conviveram entre as famílias mais influentes de Goiás (SILVA, 2009, p.65). Outro testamento, do Reverendo Padre Felipe Luiz de Carvalho, falecido em 27 de abril de 1840, legitima nove filhos, quase todos eles residem na Cidade de Goiás. Foi revelada a existência de duas genitoras: Ludovica Teixeira de Carvalho, mãe de oito filhos e Florencia de Tal, moradora do Arraial de Couros, mãe de um filho. Figueiredo ao trabalhar o cotidiano do concubinato no qual os 
padrões da Igreja pouco participavam, assegura que "a presença de filhos ilegítimos - ainda mais publicamente assumidos - evidenciava a estabilidade do relacionamento entre os casais" (FIGUEIREDO, 1997, p.120). Diferentemente de outros testamentos, a testamentária recaiu a pedido do padre sobre a sua mulher Ludovica Teixeira. Esta mulher recebeu a delegação de ser tutora dos filhos menores do padre Felipe sob a seguinte alegação: "Declaro que nomeio por Tutora de meus Filhos a minha primeira testamenteira por reconhecer que nenhuma outra pessoa será capaz de [?] e conservar os bens dos menores mais do que ella" (TESTAMENTO DO PADRE FELIPE LUIZ DE CARVALHO, 1840, p.147v). Em geral, os testamentos de padres mantêm certo silêncio em relação as suas companheiras. Padre Felipe qualifica sua mulher como pessoa capaz e competente para assumir tal preito. A proximidade de seus filhos é tanta que o próprio padre se habilitou em realizar cerimônia de casamento de sua filha Constância com José Joaquim Xavier (TESTAMENTO DO PADRE FELIPE LUIZ DE CARVALHO, 1840, p.147).

$\mathrm{O}$ adro e o altar da Igreja foram espaços que testemunharam encontros e celebrações dessas conjugalidades sacrílegas sob os olhares de familiares, amigos e pessoas próximas e residentes nesse sertão, nessa cidade. Apesar de assumir oficialmente, via testamento, a transgressão de seu celibato, o padre desejou ser enterrado com o hábito clerical, ainda que tenha assumido a sua paternidade sob o pretexto "por fragilidade humana". Para Silva Silveira, esse modelo familiar "representa a família possível, ou seja, aquela que as pessoas puderam viver, tendo vista as limitações que aquele mundo lhes impunha" (SILVEIRA, 2005, p.206-207). Os limites não impediram a constituição de uma família estável, ainda que essa fosse constituída por padres.

Outro testamento, do Cônego José Olynto da Silva, pároco colado na Freguesia de Piracanjuba, datado em 28 de junho de 1895, afirmou ter tido três filhos, duas mulheres e um homem, com a falecida Rita Gonçalves Meirelhes. O seu filho menor, José Olynto da Silva, além de ter o mesmo nome do pai, estava seguindo a carreira eclesiástica no seminário episcopal do mesmo Estado. Cônego Olynto pondera que fez o seu testamento de modo livre e sem constrangimento algum: "inscrevo de minha livre vontade e sem constrangimento ou induzimento de pessoa alguma" (TESTAMENTO DO PADRE JOSÉ OLYNTO DA SILVA,1895). Ao afirmar que a sua prole foi oriunda de sua "fragilidade humana", Cônego Olynto apenas tem por intuito facilitar a legitimação de seus filhos.

Essa fórmula legal não significa, em parte, demonstração de arrependimento pelo seu ato e vivência conjugal. É possível deduzir que a paternidade desse padre não era considerada por ele como causa de ofensa ou infâmia ao seu estado sacerdotal. Para Silva, a formulação testamentária tem por finalidade dar direcionamento à herança e reconhecer a gravidade das faltas contra o celibato eclesiástico. Basta 
[...] notar que esses eclesiásticos usufruíram da razão jurídica para fazer a legitimação de paternidade dos filhos em testamento, que permanecera lacrado. Certamente, os padres sabiam que o documento (testamento) se tornaria público após a confirmação do óbito do testador. Desse modo, o fato de os filhos serem frutos de transgressão ao celibato não causaria nenhum constrangimento ao exercício religioso do pai (SILVA, 2009, p.317).

Dois outros testamentos de Anna Joaquina Teixeira de Carvalho (23 de maio de 1846) e de Maria da Lapa de Almeida (20 de janeiro de 1858), do Arraial de Curralinho, atual cidade de Itaberaí/GO, trazem como testamenteiro de ambas o padre Joaquim Idelfonso de Almeida. A Sra. Anna Joaquina o nomeou como tutor de seus três netos menores que com ele convivem, filhos de sua filha Maria, sendo eles: João José de Almeida, Anna Crispina de Almeida e Maria da Lapa de Almeida. Esses netos foram declarados por ela como seus herdeiros universais. O que chama a atenção nesse testamento é o motivo da designação da tutoria dos netos pela sra, Anna Joaquina: "Nomeio para Tutor dos três Netos por serem ainda menores ao Reverendo Senhor Joaquim Idelfonso de Almeida como Pay que he dos mesmos meos Netos" (TESTAMENTO DE ANNA JOAQUINA TEIXEIRA DE CARVALHO, 1846, p.58). Diferentemente de sua avó, Maria da Lapa de Almeida designou o seu pai em seu testamento pelo termo padrinho, oferecendo nele apenas o nome de sua genitora Maria do Carmo Baptista Costas. Ela se apresentou na falta da legitimação por parte de seu pai como filha natural, vindo a falecer com seus dezoito anos de idade. Seu pai se tornou o herdeiro de seus pertences recebidos de sua avó materna (TESTAMENTO DE MARIA DA LAPA DE ALMEIDA, 1858, p.71v). A falta de legitimação de Maria da Lapa decorreu do motivo de somente ser possível esse processo legal aos padres via testamento, ou seja, após a morte deste. Como ela veio a falecer primeiramente esse ato legal não se consumou.

O conjunto de documentação certifica a nulidade da vivência da castidade pelos sacerdotes da Diocese de Goiás. Ida Lewcowicz é incisiva em afirmar a fragilidade do celibato, salientando "que o clero não permaneceu imune ao ambiente social que o rodeava”, sendo a vida casta o seu constante problema (LEWCOWICZ, 1987, p.58). Para Diogo Feijó, “o celibato é a origem e causa principal da imoralidade do clero" (FEIJÓ, 1999, p.306). Segundo esse padre, o problema não reside na incontinência, mas na lei que obriga os sacerdotes a serem castos, que "pelo contrário os leva pela maior parte à perdição" (FEIJÓ, 1999, p.307). Não obstante, a transgressão do celibato foi assumida pela vivência e pela exposição da conjugalidade sacrílega na Diocese de Goiás. Essa ora foi confirmada oficialmente nos testamentos deixados pelos padres e por seus ascendentes e/ou descendentes, ou ainda, manifestada via outra documentação eclesiástica ou civil, revelando a formação de uma verdadeira família constituída por princípios religiosos heterodoxos. A Igreja não conseguiu pela imposição do celibato desassociar o clero dos valores que nortearam a sociedade dos 
goyazes oitencentista. $\mathrm{O}$ amor e o afeto entre os casais e os filhos e as filhas que se originaram desta relação consolidaram sacrílegas famílias em detrimento das leis celibatárias da Igreja.

Diante do que se atem nas entrelinhas documentais, pode-se concluir que o discurso celibatário implantado em Goiás ao longo do século XIX, não surtiu o efeito desejado, muito menos trouxe consigo a reformulação da vida dos padres instalados nessa diocese. Os testamentos analisados deixam transparecer a formação de famílias autênticas, porém estas não foram reconhecidas pela instituição eclesiástica uma vez que simbolizavam a ruptura dos preceitos de castidade e de obediência e, consequentemente, manifestavam o desacordo entre a norma e o exercício do sacerdócio nas várias localidades da diocese. Havia uma distância enorme entre a legislação eclesiástica e a prática social e moral dos padres.

O sertão de Goiás favoreceu pelo seu modo de vida social e religioso, o surgimento e o reconhecimento das famílias sacrílegas. Essas conjugalidades foram vistas pela Igreja como sinônimo de desobediência e escândalo. No entanto, a população aceitava e reconhecia a conjugalidade como verdadeira e legítima, assim como a prole que dela resultava. Essa situação era tão natural que pouco ou nenhum constrangimento causava aos padres. Para Frieiro, a presença de filhos ilegítimos procedentes tanto de clérigos quanto da população em geral era uma situação corriqueira e visivelmente presente em sua análise sobre o clero mineiro influenciado pelas ideias liberais difundidas no século XIX.

Ter filhos naturais era então a cousa mais natural deste mundo: sem exceção para os padres, que costumavam ser muito bons padreadores. Casados e celibatários, clérigos e seculares, dentro e fora do matrimônio, todos pareciam apostados em povoar o mais depressa possível o nosso vasto e despovoado território (FRIEIRO, 1891, p.18).

Por um lado, o concubinato clerical pode então ser definido como a família negada pelas autoridades e normativos eclesiásticos; por outro lado, confessada e assumida pelos sacerdotes, que constituíram à margem da instituição religiosa um matrimônio marginal. A aprovação dessa conjugalidade foi circunscrita por aqueles que viveram um catolicismo culturalmente embrenhado de valores universais e regionais. Essa forma de concubinato nada mais foi do que uma alternativa produzida pela própria Igreja, que ao proibir aos padres o acesso ao matrimônio, concedeu a eles o "direito" e o "livre-arbítrio" de construírem um modelo de conjugalidade singular norteado pelo amor e o afeto entre os casais e seus filhos somente legitimados pela via do testamento cerrado.

\section{Referências Bibliográficas}


ALENCAR, Maria Amélia Garcia de. A (re)descoberta do sertão. Fragmentos de Cultura, Goiânia: Editora da UCG, v.27, n.2, p. 241-270, abr./jun., 2000.

ALMEIDA, Maria da Lapa de Almeida. Testamento, 20 de janeiro de 1858. (manuscrito - cópia xerografada). In: Testamentos de Goiás: 1852-1862. Goiânia: IPEHBC, p. 71v-73.

AQUINO, Tomás de. Suma Teológica. São Paulo: Loyola, 2005, p. 276-353. v. 7.

ASSIS, Antero Cícero de. Relatório apresentado a Assembléia Legislativa Provincial, 1872.

Memórias Goianas 11. Goiânia: Editora da UCG/Centro de Cultura Goiana, 1999, p. 115-116.

AUDRIN, Frei José M. Os sertanejos que conheci. Rio de Janeiro: José Olympio, 1963.

AZZI, Riolando. A crise da cristandade e o projeto liberal. São Paulo: Edições Paulinas, 1991.

BARBOSA, Nelson; MURARO, Luiz; PAIVA, Eliseu. Dicionário de Latim. São Paulo: Escolas Profissionais Salesianas, 1967.

BITTAR, Maria José Goulart. As três faces de Eva na Cidade de Goiás. (Dissertação de Mestrado). Universidade Federal de Goiás, Goiânia, 1997, p. 53-95.

BURKE, Peter. A cultura popular na Idade Média. São Paulo: Cia das Letras, 1993.

CARVALHO, Anna Joaquina Teixeira de. Testamento, 23 de maio de 1846. (manuscrito - cópia xerografada). In: Testamentos de Goiás: 1852-1862.Goiânia: IPEHBC, p. 58v-59v.

CARVALHO, Padre Felipe Luiz de. Testamento, 27 de abril de 1840. In: Testamentos de Goiás: 1823-1841. (digitalizado). Goiânia: IPEHBC, p. 146-150

CASTRO, José Luiz. A organização da Igreja Católica na Capitania de Goiás (1724-1824). Goiânia: Editora da UCG, 2006.

CERTEAU, Michel de. A invenção do Cotidiano - Artes de Fazer. Trad. Ephraim Ferreira Alves. Petrópolis: Vozes, 2001.

CHAUL, Nasr Fayad. Contrabando, concubinato e ócio nas raízes de Goiás. Fragmentos de Cultura, Goiânia: Editora da UCG, 1998, jul./ago, v.8, n.4, p. 1031-1047.

CONCÍLIO ECUMENNICO DE TRENTO. Associação Cultural MONTFORT.

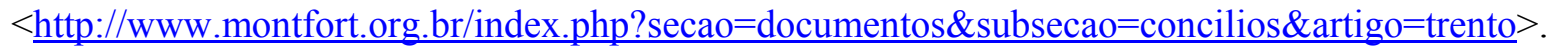
Acessado em 22/01/2008.

FIGUEIREDO, Luciano Raposo de Almeida. Barrocas Famílias: vida familiar em Minas Gerais no século XVIII. São Paulo: HUCITEC, 1997.

FEIJÓ, Diogo Antonio. Demonstração da necessidade de abolição do celibato clerical (1828). In: CALDEIRA, Jorge (org.). Coleção Formadores do Brasil: Diogo Antonio Feijó. São Paulo: Editora 34, 1999, p. 278-357.

FLADRIN, Jean-Louis. A vida sexual dos casados na sociedade antiga: da doutrina da Igreja à realidade dos comportamentos. In: ARIÈS, Phippe; BÉJIN, André (orgs). Sexualidades Ocidentais. 
Trad. Lygia Araújo Watanabe e Thereza Christina Ferreira Stummer. São Paulo: Brasiliense, 1987, p. 135-152.

FRIEIRO, Eduardo. O diabo na livraria do cônego. São Paulo: Editora da USP, 1981.

GRAGEDA, Blanca Estela Gutiérrez. Celibato clerical, concubinato y matrimonio civil. Una visión liberal del siglo $X I X$. $<\underline{\mathrm{http}}$ //www.uaq.mx/voces/n07/celibato clerical.html $>$. Acessado em 02/07/08.

LEÃO, Dom Claudio José Gonçalves Ponce de. Carta Circular (Reservada). Dirigida aos Parochos e aos demais Clerigos de Ordens Sacras da Diocese de Goyaz. Goyaz: 1885, TypografiaPerseverança de Tocantins y Aranha. In: Coleção Especial do Cônego Trindade. N. 421. Goiânia: IPEHBC.

. Carta Pastoral. Annunciando e Convocando o Synodo Diocesano. Goyaz: 1887. In: Coleção Especial do Cônego Trindade. N. 421. Typografia-Perseverança de Tocantins y Aranha. Goiânia: IPEHBC.

LEONARDI, Victor. Entre árvores e esquecimentos: história social nos sertões do Brasil. Brasília: 1996, p. 307-322.

LEWCOWICZ, Ida. A fragilidade do celibato. In: LIMA, Lana Lage. Mulheres, adulteros e padres - história e moral na sociedade. Rio de Janeiro: Dois Pontos, 1987, p. 55-68.

LIMA Nísia Trindade Lima. Um sertão chamado Brasil. Rio de Janeiro: IUPERJ/UCAN, 1998, p. $35-53$.

LIVRO DE TOMBAMENTOS DA DIOCESE DE GOIÁS. HISTÓRICOS, LIMITES, PROVIMENTO E PATRIMÔNIO. Freguesia de Bela Vista. 1920. p. 29-29v. Goiânia: IPEHBC.

MIRANDA, Beatriz V. Dias. O Bem Morrer: religiosidade popular e organização social. In: MIRANDA, Beatriz V. Dias; PEREIRA, Mabel Salgado. Memórias Eclesiásticas: Documentos Comentados. Juiz de Fora: Editora UFJF - CEHILA/MG, 2000, p. 14-22.

NEVES, Maria de Fátima R. das. O sacrilégio permitido: filhos de padres em São Paulo Colonial. In: MARCÍLIO, Maria Luiza. Família, mulher, sexualidade e Igreja na história do Brasil. São Paulo: Loyola/CEDHAL-CEHILA, 1993, p. 135-189.

PINTO, Luiz Maria da Silva. Diccionario da Lingua Brasileira. (Edição fac-similar). Goiânia: Editora da UCG, 1996.

PALACÍN, Luis. O século do ouro em Goiás (1722-1822): estrutura e conjuntura numa capitania de minas. Goiânia: Editora da UCG, 2001.

POHL, Joahnn Emmanuel. Viagem ao interior do Brasil. São Paulo: Edusp, 1976.

PROVINCIA DE GOYAZ. (jornal impresso). Goiânia: AHE, 09 de julho de 1870, p. 2.

RANKE-HEINEMANN, Uta. Eunucos pelo Reino de Deus. Trad. Paulo Froés. Rio de Janeiro: Rosa dos Tempos, 1988.

RELATÓRIO DO CHEFE DE POLÍCIA. Documentos manuscritos avulsos. Goiânia: AHE, 1866, Caixa 173. 
SAINT-HILAIRE, Auguste. Viagem à Província de Goiás. Trad. Regina Regis Junqueira. Belo Horizonte: Itatiaia; São Paulo: USP, 1975.

SERRADOURADA, Padre José Iria Xavier. Testamento-Cerrado. 04/09/1898. (documento manuscrito). Cidade de Goiás: Arquivo Frei Simão Dorvi,.

SILVA, Andréia Lopes Frazão da; LIMA, Marcelo Pereira. A reforma papal, a continência e o celibato eclesiástico: considerações sobre as práticas legislativas do pontificado de Inocêncio III (1198-1216). < http://www.abrem.org.br/papals.pdf>. Acessado em 14/05/2008.

SILVA, Dom Eduardo Duarte da. Passagens: Autobiografia de Dom Eduardo Duarte da Silva, Bispo de Goyaz. Goiânia: Editora da UCG, 2007.

. Portaria. Goyaz: Typographia de Abreu Bastos, 1891. Goiânia: IPEHBC.

SILVA, José Trindade da Fonseca e. Lugares e Pessoas: Subsídios eclesiásticos para a história de Goiás. Goiânia: Editora da UCG, 2006.

SILVA, Maria Beatriz Nizza da. Sistema de casamento no Brasil Colonial. São Paulo: EDUSP, 1984.

SILVA, Maria da Conceição. Catolicismo e casamento civil em Goiás, 1860-1920. Goiânia: Editora da UCG, 2009.

SILVA, Maria da Conceição. A ausência do celibato na Cidade de Goiás no século XIX:

concupiscência e pecado. VARIA HISTÓRIA, Belo Horizonte: Departamento de História da UFMG, v.25, n. 41, p.317-331, 2009.

SILVA, Padre José Olynto da. Testamento, 28 de junho de 1895. (cópia datilografada). Goiânia: IPEH-BC.

SILVEIRA, Alessandra da Silva. O amor possível: um estudo sobre o concubinato no Bispado do Rio de Janeiro em fins do século XVIII e XIX. (Tese de Doutorado). 2005.

$<$ http://libdigi.unicamp.br/document/?code $=$ vtls000374338 $>$. Acessado em 08/05/2007.

SYNODO DE ELVIRA. 2008. < http://www.aciprensa.com/sacerdocio/elv.htm>. Acessado em 08/04/09.

SOUZA, José Antonio da Silva e. Testamento, 26 de junho de 1840. In: Testamentos de Goiás: 1823-1841. (digitalizado). Goiânia: IPEHBC, p. 154v-157.

SOUZA, Luiz Antonio da Silva e. Testamento, 30 de setembro de 1840. In: Testamentos de Goiás: 1823-1841. (digitalizado). p. 170-174. Goiânia: IPEHBC.

SOUZA, Maria Luiza da Silva e. Testamento, 23 de setembro de 1843. In: Testamentos de Goiás: 1843-1852. (xerox de manuscrito). p. 11-14. Goiânia: IPEHBC.

. Livro de Vizitas Pastorais de 1734-1824. (cópia datilografada). Goiânia: IPEHBC, 25/03/1824.

TELES, José Mendonça. Vida e obra de Silva e Souza. Goiânia: Oriente, 1977. 
TORRES-LONDOÑO, Fernando. A outra família: concubinato, Igreja e escândalo na colônia. São Paulo: Edições Loyola, 1999.

TRISTÃO, Roseli Martins. Formas de vida familiar na cidade de Goiás nos séculos XVIII e XIX. 1998. Dissertação (Mestrado em História) - Universidade Federal de Goiás, Goiânia, 1998.

VAINFAS, Ronaldo. Casamento, amor e desejo no ocidente cristão. São Paulo: Ática, 1986.

. Moralidades brasílicas: deleites sexuais e linguagem erótica na socie-dade escravista. In: SOUZA, Laura de Mello e (org.). História da vida privada no Brasil: co-tidiano e vida privada na América portuguesa. São Paulo: Companhia das Letras, 2007, p. 221-273.

VALDEZ, Diane. Filhos do pecado, moleques e curumins: imagens da infância nas terras goianas do século XIX. (Dissertação de Mestrado). Universidade Federal de Goiás, 1999, p. 25-71.

VALLE, Padre Dr. Alexandre Marquez. Livro de Vizitas Pastorais de 1734-1824. (cópia datilografada) Goiânia: IPEHBC.

VIDE, Dom Sebastião Monteiro da. Constituições Primeiras do Arcebispado da Bahia. (Edição

fac-similar do livro impresso em 1853). Brasília: Senado Federal, 2007.

\section{NOTAS}

1 As Constituições primeiras do Arcebispado da Bahia correspondem às primeiras leis canônicas construídas em solo brasileiro em 1707. Dada ausência de um corpo leis que unificasse o catolicismo no Brasil, D. Sebastião Monteiro da Vide convoca neste ano um Sínodo Diocesano, cujo objetivo seria uniformizar a administração dos sacramentos e do exercício do sacerdote com base no Concílio de Trento (Cf. TORRES-LONDOÑO, 1999, p.117-123).

2 As Visitas Pastorais consistiam na visita de um bispo ou de um vigário nomeado, chamado visitador, a uma determinada diocese, no intuito de averiguar a vida moral do clero e da população local, além de verificar o estado das Igrejas, o cumprimento das funções litúrgicas e a aplicação da justiça. O objetivo das visitações diocesanas, "de acordo com a orientação tridentina, era estabelecer a doutrina sã e excluir as heresias" (CASTRO, 2006, p.45). Cônego Trindade traça um retrato detalhado das Visitas Pastorais e de seus visitadores com base cronológica e pastoral (SILVA, 2006, p.78-91).

3 "De portas a dentro" - mulher que se encontra sobre os cuidados financeiros de um homem, e com ele partilha a sua vida - teúda (mulher tida) e manteúda (mulher mantida).

${ }^{4}$ Existiam dois tipos de impedimentos: os impedientes e os dirimentes. "No primeiro caso, o matrimônio celebrado era válido perante a Igreja, mas os contraentes cometiam pecado mortal, no segundo caso, além do pecado mortal, o matrimônio celebrado era considerado nulo". Para sanar esta situação a Igreja criou a prática das dispensas matrimônio, na intenção de se legalizar a união de casais, em consonância com as normas eclesiásticas que regem o Sacramento do Matrimônio. (SILVA, 1984, 126-139).

${ }^{5}$ Frei José M. Audrin - Missionário Dominicano - Residiu inicialmente em Uberaba por volta de 1902. Em 1904, parte para o sertão de Goiás e do Pará. "Trabalha em Conceição do Araguaia, posto extremo da missão dominicana, até 1921. Dirige o Convento Dominicano de Pôrto Nacional de 1921 a 1928. Retorna a Conceição do Araguaia em 1929” (Cf. Nota da Editora José Olympio - Os Sertanejos Que Eu Conheci, 1963).

${ }^{6}$ Cf. BITTAR, 1997, p.53-95; CHAUL, 1998, p.1031-1047; PALACIN, 2001; TRISTÃO, 1998; VALDEZ, 1999, p.2571.

7 O Livro Terceiro das Constituições do Arcebispado da Bahia traz todo um conjunto de normativos específicos para a reformulação da conduta do clero no Brasil. A vida moral, vestimentas, lugares permitidos ou não aos padres, controle dos prazeres carnais e sexuais são sinalizados neste livro como sinais ideais de diferenciação do clero e do laicato. Um de seus pontos centrais tange à observância do celibato eclesiástico, uma vez que um dos intuitos centrais deste livro é “domínio dos corpos”. Ver Constituições Primeiras do Arcebispado da Bahia, Livro III, Título I ao XXXIX. 
Artigo recebido em 05/2010. Aprovado em 06/2010. 